\title{
Split-Hand/Foot Malformation Type 3
}

National Cancer Institute

\section{Source}

National Cancer Institute. Split-Hand/Foot Malformation Type 3. NCI Thesaurus. Code C75121.

Split-hand/foot malformation mapped to chromosome 10q24. 